Chapter 11

\title{
DNA-Dependent RNA Polymerases of the Archaebacteria
}

\author{
- W. Zillig, K. O. Stetter, R. Schnabel and M. Thomm \\ I. Transcription in Eubacteria . . . . . . . . . . . . . . . . . . . . 499

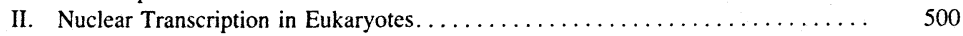 \\ III. DNA-Dependent RNA Polymerases of Archaebacteria . . . . . . . . . . . . 501

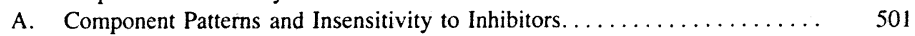 \\ B. Homologies among Archaebacterial RNA Polymerases ............. 503 \\ C. Homology between Archaebacterial and the Nuclear Eukaryotic RNA \\ Polymerases. . . . . . . . . . . . . . . . . . . . . . . . . . 507 \\ D. Purification of Archaebacterial RNA Polymerases .............. 513 \\ E. Different Forms and Fragments of Archaebacterial RNA Polymerases..... 514

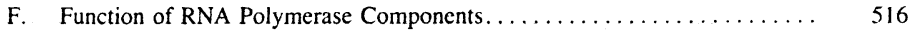 \\ G. In Vitro Transcription by Archaebacterial RNA Polymerases . . . . . . . . . 517

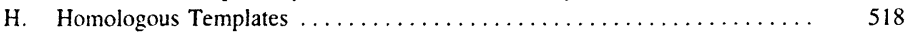

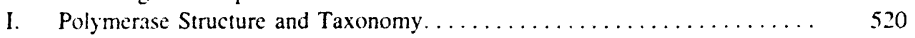

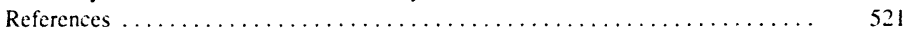

\section{Transcription in Eubacteria}

DNA-dependent RNA polymerase holoenzymes of eubacteria have the standard composition $\beta^{\prime} \beta \alpha_{2} \sigma$ in which $\beta^{\prime} \beta \alpha_{2}$ is the core enzyme, involved in elongation, and $\sigma$ the initiation factor released soon after initiation of transcription (Burgess, 1976; Zillig et al., 1976; Zillig and Stetter, 1980). The role of a normally occurring small component, $\omega$, in enzyme function remains obscure. Depending on the mode of preparation, additional proteins, sometimes bound less tightly to the polymerases than the "normal" components, occur in fractions of them, e.g. $\delta$ in the RNA polymerase of Bacillus subtilis (Pero et al., 1975), $\gamma$ and $y$ in that of Lactobacillus (Stetter and Zillig, 1974; Stetter, 1977; Gierl et al., 1982). They are engaged in special transcription functions. Variations do not occur in the principal composition but in details, e.g., the relative size of the $\beta^{\prime}$ versus the $\beta$ chain (the former being larger than the latter in Escherichia coli and other gram-negative bacteria but smaller in gram-positive bacteria), the large molecular weight of $\sigma$ in many gram-negative bacteria as opposed to its small size in gram-positive bacteria, and the corresponding occurrence of binding proteins in gram-positive bacteria ( $\delta$ in Bacillus and $\gamma$ and $y$ in Lactobacillus). 
RNA polymerases of different eubacteria resemble each other in recognizing the same promoters, e.g., those in coliphage T7 DNA (Wiggs et al., 1979), and thus define, in the limit, "the eubacterial promoter."

Little is known about the function of enzyme components. The $\beta$ subunit of both gram-negative and gram-positive bacteria forms a complex, $\beta \alpha_{2}$, with the $\alpha$ subunits. This complex binds rifampicin (Zillig et al., 1976). In gram-negative bacteria, the sites of interaction of RNA polymerase with the antibiotics rifampicin and streptolydigin both map in the $r p o B$ gene (Heil and Zillig, 1970). In gram-positive bacteria that for rifampicin is also in $r p o B$, that for streptolydigin, however, is in rpoC (Halling et al., 1978).

Antibodies against eubacterial RNA polymerases do not form precipitation lines with RNA polymerases from members of different families of eubacteria in Ouchterlony's in-gel immunodiffusion test (K. O. Stetter, unpublished), though the homology of the components of enzymes from different families was demonstrated by intergeneric reconstitution (Lill et al., 1975) and by means of antisera against single subunits (Leib et al., 1980).

Thus, both the compositions and the functions of all known eubacterial RNA polymerases conform to a prototype, but variations in detail reflect phylogenetic divisions, and can therefore be used for taxonomic purposes.

\section{Nuclear Transcription in Eukaryotes}

The nuclear DNA-dependent RNA polymerases of eukaryotes are of higher complexity, containing 9 to 12 , or more, components, than those of eubacteria. Moreover, three types of polymerase exist that differ in most of their components and transcribe different classes of genes: RNA polymerase I(A) produces rRNA, including 5.8 S rRNA, RNA polymerase II(B) produces mRNA, and RNA polymerase III(C) produces tRNA and $5 \mathrm{~S}$ rRNA. RNA polymerase I is insensitive to the fungal toxin $\alpha$-amanitin; RNA polymerase III shows low and RNA polymerase II shows high sensitivity to the drug. On the other hand, rifampicin and streptolydigin inhibit none of these three enzymes (Roeder, 1976).

The homology between the components of the three functionally different RNA polymerases and also between enzymes from different phyla of eukaryotes has been demonstrated immunochemically by challenging the (spotted) enzymes or Western blots of their components with antibodies against single enzyme components (Huet et al., 1982).

Each of the three functionally different RNA polymerases recognizes corresponding promoters of a distinct type. None of these show -10 and -35 sequences closely resembling those characteristic for eubacterial promoters.

Almost nothing is known about the function of the components of these 
eukaryotic enzymes. Dissociation and reconstitution approaches, which have helped in elucidating the role of the components of bacterial RNA polymerases (Heil and Zillig, 1970); Palm et al., 1975; Ishihama and Ito, 1972), have not yet been worked out for the eukaryotic RNA polymerases.

In summary, eukaryotic and eubacterial RNA polymerases are clearly distinguished by component patterns and functional characteristics such as promoter recognition sites, which would be expected for homologous molecules from different primary kingdoms.

\section{DNA-Dependent RNA Polymerases of Archaebacteria}

\section{A. Componint Patterns and Insensitivity to Inhibitors}

As expected, DNA-dependent RNA polymerases from members of the third primary kingdom, the archaebacteria, differ characteristically from the corresponding enzymes of both eubacteria and eukaryotes (Zillig and Stetter, 1980; Zillig et al., 1982a,h; Prangishvilli et al., 1982) (Fig. 1). In contrast to the polymerases from eubacteria, but like the nuclear enzymes of eukaryotes, the polymerases contain 7 to 12 different components. The two heaviest components exhibit a larger size difference than do the $\beta^{\prime}$ and $\beta$ subunits of most eubacterial enzymes. The two following types of archaebacterial RNA polymerases have been distinguished on the basis of their component patterns.

I. The RNA polymerases of Thermoplasma (Sturm et al., 1980; Zillig et al., 1979, 1980), Sulfololus, and the extremely thermophilic, anaerobic, sulfurdependent Thermoproteales (Prangishvilli et al., 1982; Zillig et al., 1983a,b) contain three large components, including component $C$ (about 40,000 daltons), in a $1: 1: 1$ ratio. However, in eubacteria, component $\alpha$, which corresponds in size to $\mathrm{C}$, is present in two copies per enzyme monomer. Furthermore the archaebacterial enzymes of this type apparently lack a component corresponding in size to the eubacterial $\sigma$ component.

2. The RNA polymerases of Methanobacterium (Stetter et al., 1980), Methanococcus, Methanosarcina (Thomm, 1983), and Halobacterium (Zillig et al., 1978) contain four instead of three heavy components, all in one copy per monomer.

All archaebacterial RNA polymerases isolated so far are insensitive to as much as $100 \mu \mathrm{g} / \mathrm{ml}$ of the antibiotics rifampicin and streptolydigin, the former normally inhibiting initiation, the latter inhibiting elongation by eubacterial RNA polymerases (Table I). The rifampicin sensitivity of Halobacterium halobium is due to a detergent-like effect of the antibiotic, which leads to cell lysis at 


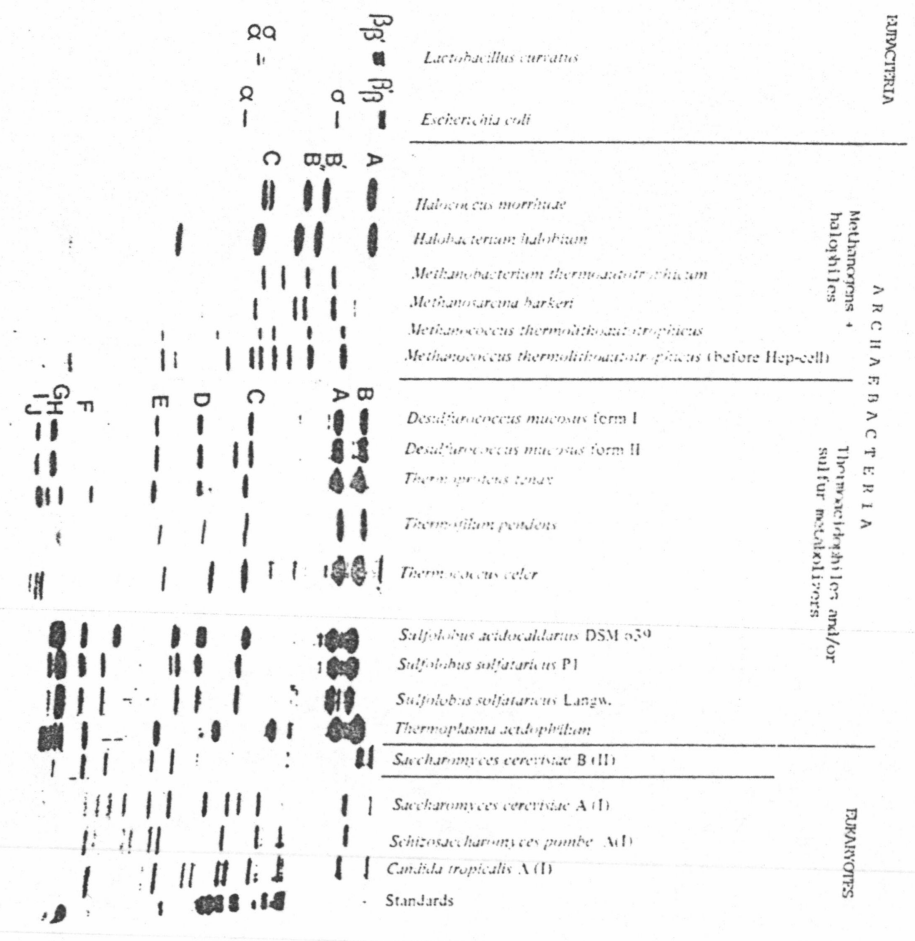


concentrations above $10 \mu \mathrm{g} / \mathrm{ml}$ (Zillig et al., 1978). However, archaebacterial transcriptases are also insensitive to the fungal toxin $\alpha$-amanitin, which inhibits eukaryotic RNA polymerase II(B) and (less efficiently) III(C) (Table I).

Aside from their one major difference (three instead of four heavy components), the component patterns of the RNA polymerases of the thermoacidophiles and the methanogens (including the extreme halophiles) appear similar to each other. Homology between small components of the different archaebacterial enzymes is indicated (1) by the observation that components of comparable relative mobility resemble each other in appearance on (stained) SDS-polyacrylamide gels, e.g., component $\mathrm{D}$ is often a rather diffuse double band, and exhibits a distinct tinge after staining with Coomassie blue and (2) by their stoichiometry. In the RNA polymerases from Sulfolobus and the Thermoproteales, two small components ( $G$ and $I$ ) appear to be present twice per enzyme monomer, whereas another $(F)$ is sometimes absent or occurs in substoichiometrical amounts.

\section{B. Homologies among Archaebacterial RNA Polymerases}

With the aim to find more certain criteria for the homology of components of different archaebacterial RNA polymerases, Western blots of their SDS-polyacrylamide gel electrophoretic patterns on nitrocellulose shects (Towbin et al., 1979; Burnette, 1981; Huet et al., 1983) were challenged with rabbit antibodies against single components of the RNA polymerases of Sulfolobus and of Methanobacterium (Schnabel et al., 1983a) (Fig. 2). Specific binding was visualized either with iodinated protein $\mathrm{A}$ or with peroxidase, coupled to a goat antirabbit antiserum plus $o$-dianisidine and $\mathrm{H}_{2} \mathrm{O}_{2}$.

The antiserum against the heaviest component of Sulfolobus polymerase reacted with the heaviest components of all other RNA polymerases from thermoacidophilic (including sulfur-dependent) archaebacteria, but reacted with the second and third components of the enzymes from the methanogens and with the second from Halobacterium. Conversely, the antiserum against the heaviest component of the Methanobacterium polymerase recognized the second component of the thermoacidophile polymerases (except for Thermococcus) but reacts with the heaviest component from other methanogens and the extreme halophiles.

As expected, antiserum against the second component of Sulfolobus reacts

Fig. 1. Component patterns of DNA-dependent RNA polymerases from eubacteria (L. currutus and E. coli), archaebacteria, and eukaryotes [Saccharomyces polymerases $\mathrm{B}(\mathrm{II})$ and $\mathrm{A}(\mathrm{I})$ and Schizosaccharomyces and Candida RNA polymerase A] obtained by SDS-polyacrylamide gradient slab $\mathrm{gcl}$ electrophoresis. 


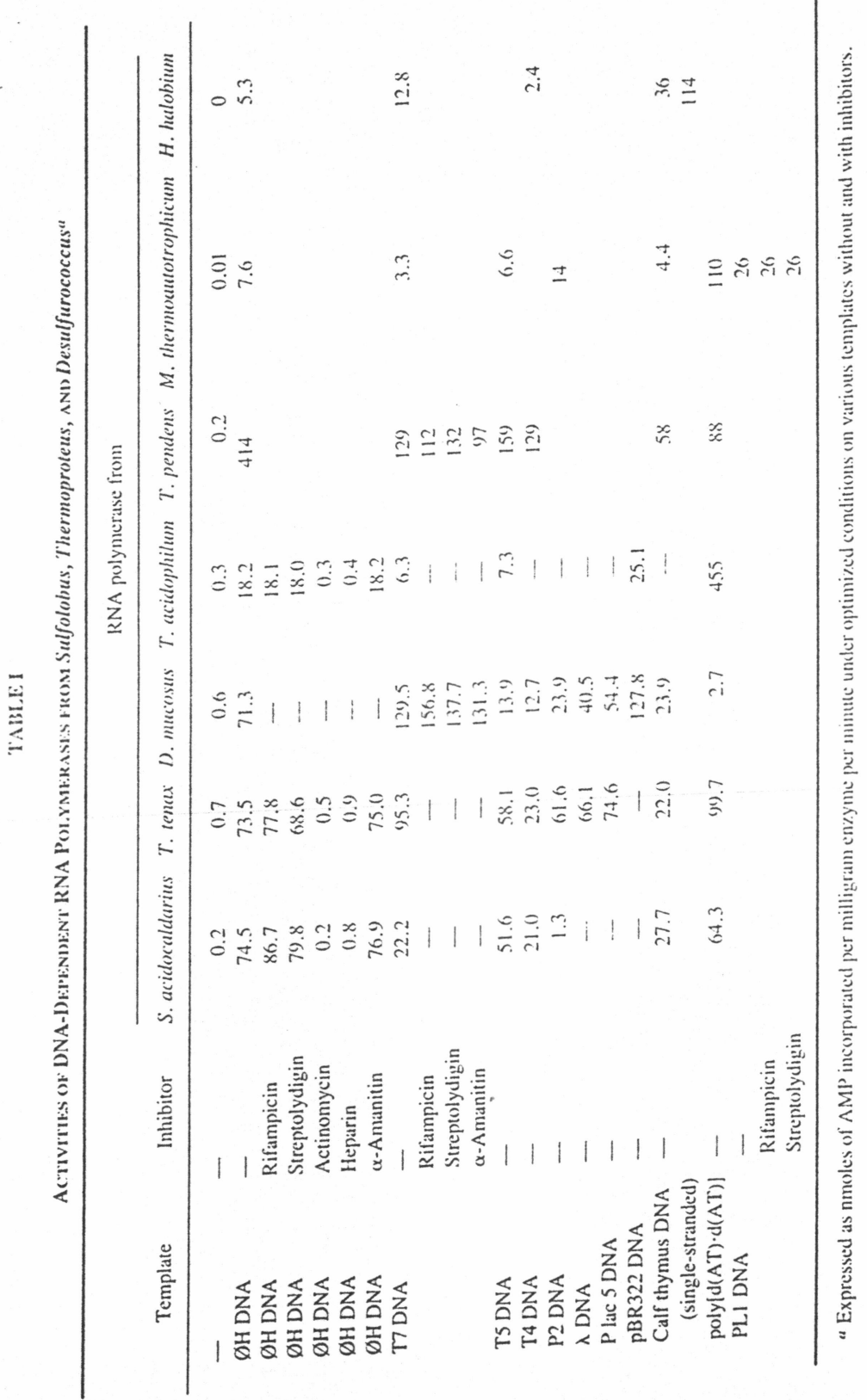


anti-Sulf $B$ anti-Sulf

S.a. Th.a. D.m. To.t. Tc.c. H.h. M.th.

S.o. Th.o. D.m. Tp.t. Ic.c. H.h. M.th.
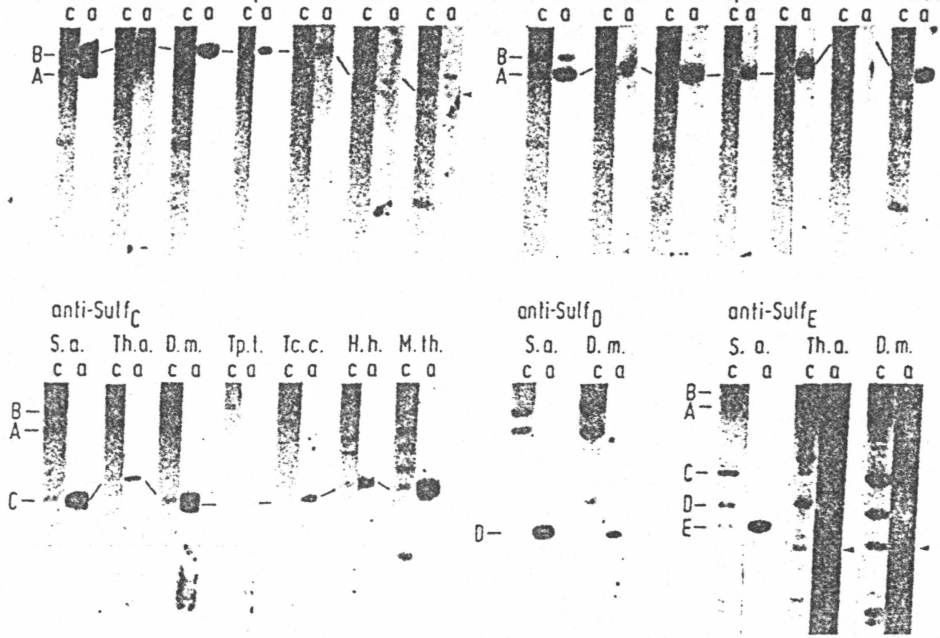

Fic. 2. Homologies of the components of the archatebacterial D.VA-dependent R.VA polymerases. Component paterns of the enzymes obtained by SDS. polyarylamide gel electrophoresis. transferred to nitrocellulose filters [Western blots (Towbin at al. 1979; Burnette. 19811] were challenged with antibodies raised against the single components of two archaebaterial R.NA polymerases (Schnabel et al., 1983). (A) Cross-reactions with antibodies against the cemponents of the RNA polymerase of Sulfolobus acidocaldarius. Bound antibodies were visualized by 12s I-labeled protein $A$. tracks labeled a. Tracks labeled $\mathrm{c}$ show the components directly visualized by Coomassie blue staining. Abbreviations: S.a., Sulfolobus acidocaldarius: Th.a.. Thermeplasma acidophilum: D.m., Desulfirococius mucosus; Tp.t., Thermoproteus tenax; Te.c., Thermococus celer: H.h., Halobacterium halobium: M.th., Methanobacterium thermoautotrophicum. (B) Cross-reactions with antibodies against the components of the RNA polymerase from. Methanobacterium thermonutotrophicum. Bound antibodies were visualized by 125 - labeled protein A. (C) Cross-reaction of antibodies against the components of the RNA polymerase from Methanobacterium thermoatutotrophicum with components of the RNA polymerase of Methanosarcina burkeri and Methanococius thermolithotrophicus and of antibodies against component B of the RNA polymerase of Sulfolobus acidocaldarius with the components $\mathrm{B}$ and $\mathrm{B}^{\prime}$ of the enzymes of methanogenic archaebacteria. The tracks labeled p show the bound antibodies (Towbin et al., 1979) Abbreviations: .Ig.th., Methanobacterium thermoautotrophicum; Mc.th., Methanococcus thermolithotrophicus: Ms.b., Methanosarcina burkeri. (See pp. 506-507.)

with the second component of other thermoacidophiles but reacts with the first component of the methanogen enzyme, whereas antibody against the second component of the methanogen polymerase reacts with the second component of other methanogen polymerases but reacts with the first component of the thermoacidophile polymerases. Again, as expected, antiserum against the third com- 


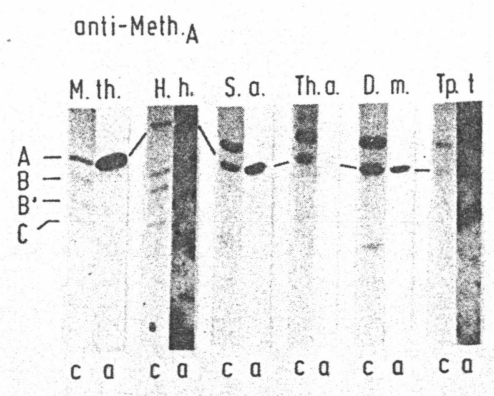

$$
\text { anti-Meth. B }
$$
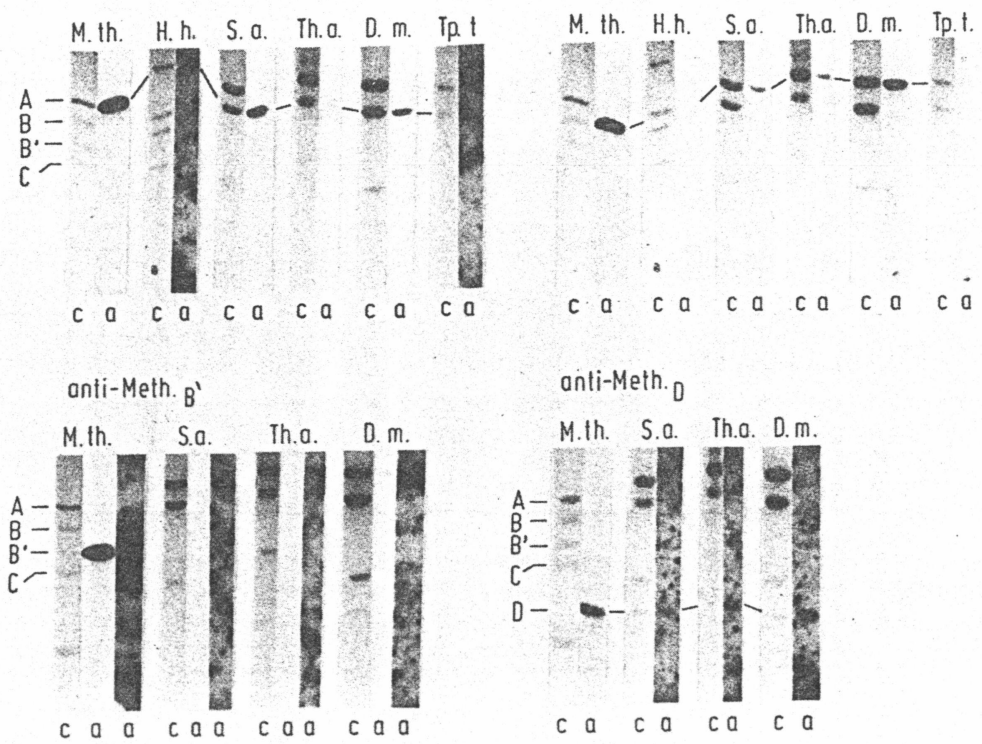

Fig. 2-B. (Continued)

ponent of the methanogen enzyme also reacts with the first component of the thermoacidophile enzyme, but reacts with the third component from other methanogens. Antiserum against the third component of Sulfolobus binds to the third components from other thermoacidophiles but binds to the fourth components from methanogens and halobacteria. Antibody against the fourth component from a methanogen reacts with the fourth component from other methanogens, but reacts with the third component of thermoacidophilic polymerases. The antibody against the fourth and fifth components from Sulfolobus react as expected with the components from the other thermoacidophiles. Antibodies against the fifth component from a methanogen react with the fourth component from the thermoacidophiles.

These cross-reactions prove the homology between (the heavier components of) the RNA polymerases of the two main branches of the archaebacteria. However, the two heaviest components appear in opposite sequence in the patterns of the thermoacidophiles as opposed to those of the methanogens and halophiles, and the heaviest components of the thermoacidophiles correspond to the second plus the third component from the methanogens. This is, however, not due to an immunochemical relation between these last two, because they do not cross-react 


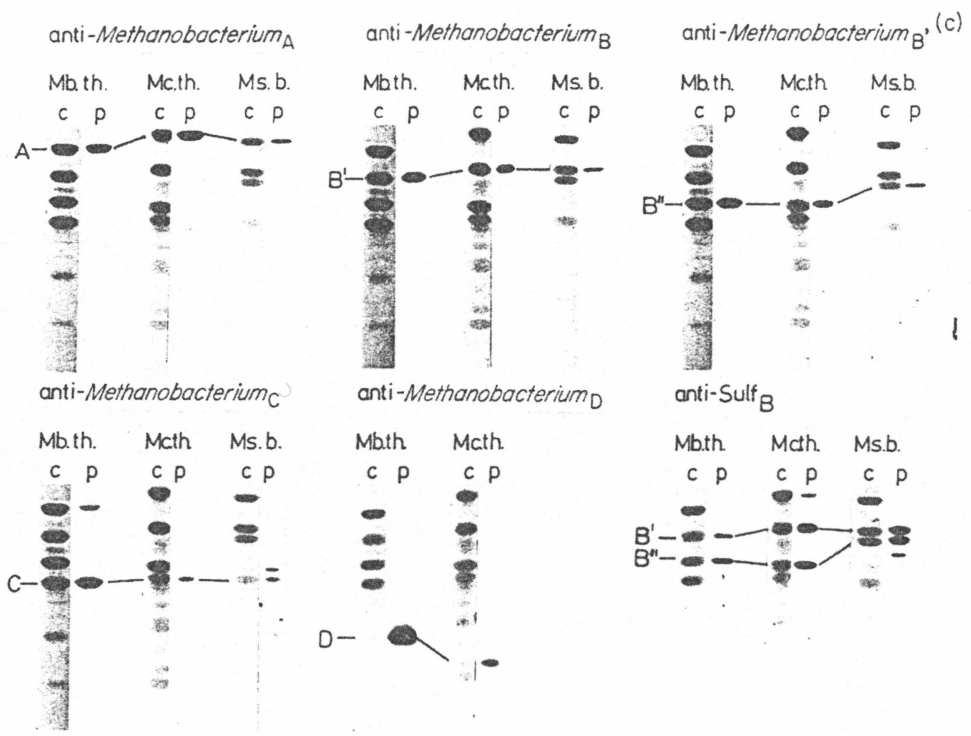

FIG. 2-C.

with each other. These two must, therefore, carry homologies to different parts of the (larger) first component of the thermoacidophiles.

In view of the fact that immunochemical cross-reactions reflect sequence and thus phylogenetic and probably functional homology, we propose to name homologous components of different RNA polymerases with the same large Roman letters.

Thus, the archaebacterial enzymes belong to either of two types (Fig. 3). All RNA polymerases from thermoacidophilic (and/or sulfur-dependent) archaebacteria, including Thermoplasma, have the composition BACDE(FG2HI2J) in which the sequence of symbols is in the order of the decreasing apparent size and the parentheses indicate lack of immunochemical evidence. All RNA polymerases from methanogens and extreme halophiles studied so far have, in contrast, the component pattern $\mathrm{AB}^{\prime} \mathrm{B}^{\prime \prime} \mathrm{CD}$. . . .

\section{Homology between Archaebacterial and the Nuclear EUKARYOTIC RNA POLYMERASES}

The same method of immunochemical analysis that has led to the establishment of the homologies between the components of archaebacterial RNA poly- 


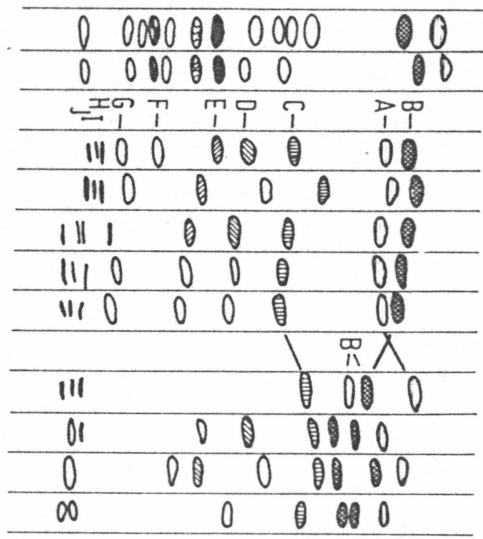

$\left.\begin{array}{l}\text { Pol A } \\ \text { Pol B }\end{array}\right\}$ Yeast

Sulfolobus acidocaldarius

Thermoplasma acidoohilum

Desulfurococcus mucosus

Thermoproteus tenax

Thermococcus celer

Halobacterium halobium

Methanobacterium thermoautotrophicum

Methanococcus thermolithotrophicus

Methanosarcina barkeri

FIG. 3. Schematic representation of the homologies shown in Figs. 2 and 5. For the homologies of the yeast RNA polymerases with each other, see Huet et al., 1982.

merases had previously been used for the investigation of a possible correspondence between components of polymerases from nuclear eukaryotic and those from archaebacterial enzymes (Huet et al., 1982) (Figs. 4 and 5).

Antibody against the heaviest single component A190 of yeast RNA polymerase $\mathrm{I}(\mathrm{A})$ reacted with spots of all but one of the archaebacterial RNA polymerases, but among eubacteria, reacted only with the polymerase of $E$. coli. Antibody against A135 bound to all archaebacterial enzymes tested. The antiserum against A49 bound to the Thermoplasma and Halobacterium polymerases; the antiserum against A40 bound to the enzymes from Sulfolobus, Desulfurococcus, Halobacterium, and Methanobacterium, and the antisera against A34.5, A25, and A14.5/14 bound to the Halobacterium polymerase.

The antisera against B220 or its proteolysis product B185 reacted with four of five archaebacterial enzymes but with none of the three eubacterial polymerases; the antiserum against B150 reacted with the enzymes from Thermoproteus and Halobacterium.

On Western blots, Anti A190 and Anti B185 reacted with the second component of the thermoacidophilic and (its counterpart) the first component of the Halobacterium enzyme, termed A (see previous paragraph). Anti A135 and Anti $\mathrm{B} 150$ were bound to the first component of the thermoacidophilic and to the second component of Halobacterium polymerase (now termed B). The other significant cross-reactions obtained with the spot tests could not be specified by challenging Western blots.

The cross-reaction between eukaryotic and eubacterial enzymes is limited to one or the other component. Quantitatively, it is much less pronounced. 


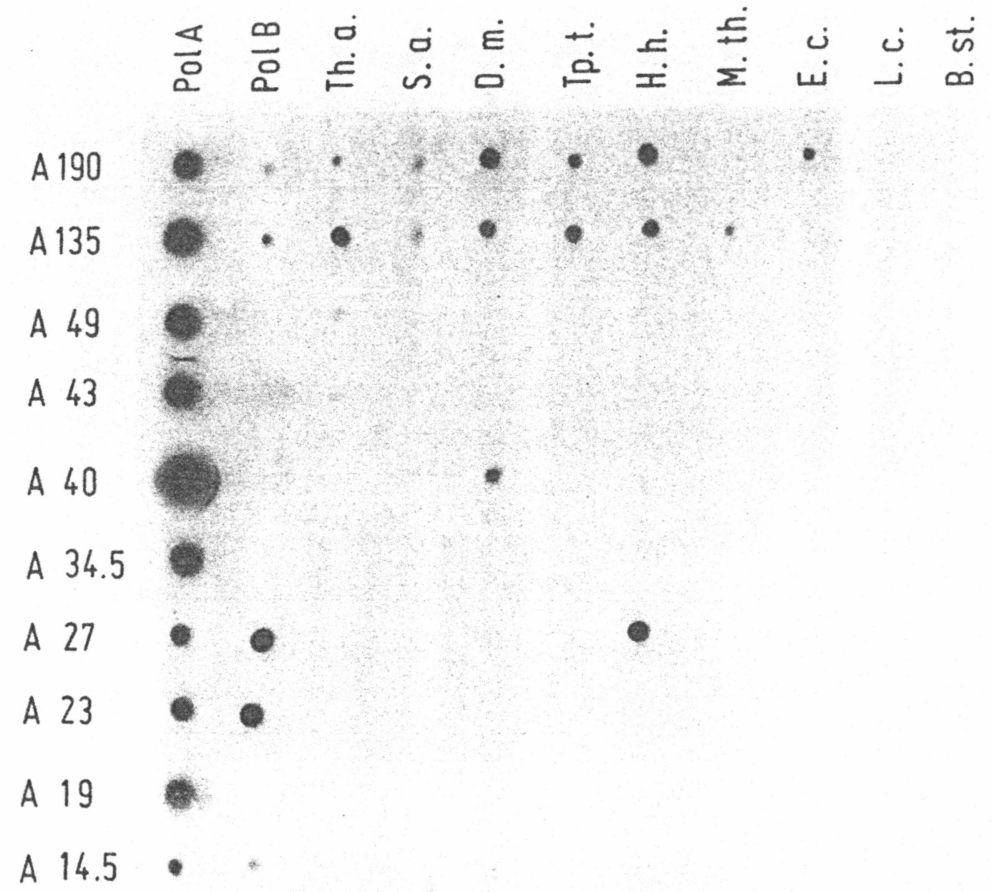

\section{A 12}

PolA

FIG. 4. Immunological spot test of eukaryotic, archaebacterial, and eubacterial RNA polymerases. RNA polymerases were spotted on nitrocellulose filters and challenged with antibodies raised against the native RNA polymerases $\mathrm{A}(\mathrm{I})$ (PolA) and $\mathrm{B}$ (II) (PolB) of yeast and against their single components as specified by their molecular weights. Bound antibodies were visualized by incubation with ${ }^{25}$ I-labeled protein A. (For details, see Huet et al., 1982, 1983.) Abbreviations: S.a., Sulfolobus acidocaldarius; Th.a., Thermoplasma acidophilum; D.m., Desulfurococcus mucosus; Tp.t., Thermoproteus tenax; H.h., Halobacterium halobium; M.th., Methanobacterium thermoautotrophicum; E.c., Escherichia coli; L.c., Lactobacillus curvatus; B.st., Bacillus stearothermophilus. (continued) 


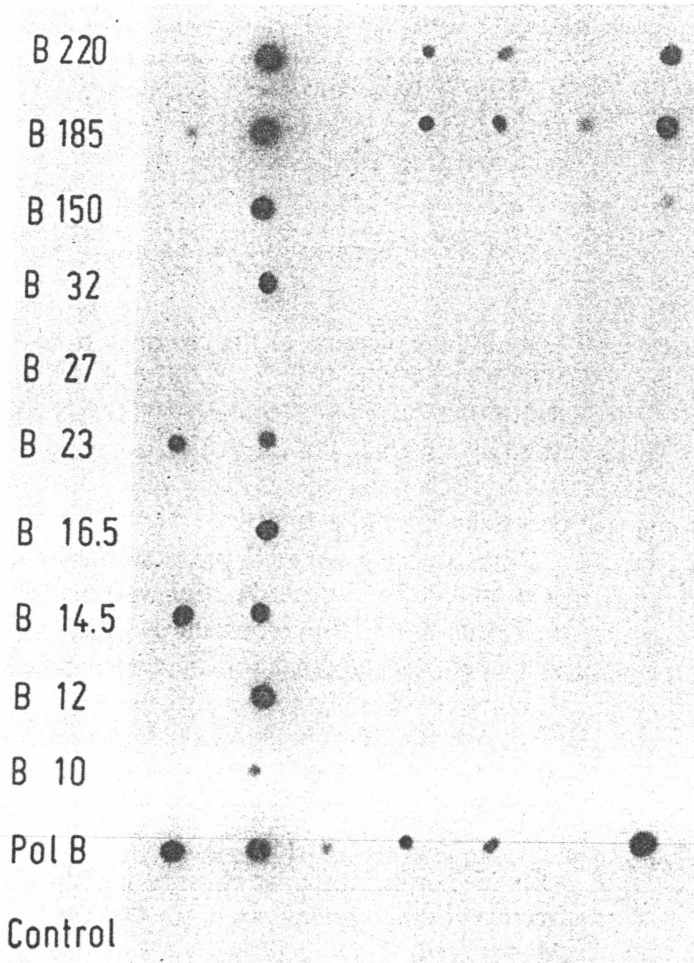

Fig. 4. (Continued)

The cross-reaction between eukaryotic and archaebacterial enzymes and their components is sometimes stronger than between homologous components of RNA polymerases I and II from yeast.

1. The Flavonolignane Derivative Silybin Stimulates

TransCription by ARChaEbacterial RNA Polymerases

Further evidence for the striking homology of archaebacterial and eukaryotic RNA polymerases is furnished by the finding that the flavonolignane derivative

Fig. 5. Homologies of the large components of the RNA polymerases of some archaebacteria and yeast. Antibodies raised against the two largest components of polymerase A(I) (A190, A135) and B(II) (B185, B150) were used. (For details see Fig. 2 and Huet et al., 1983.) 


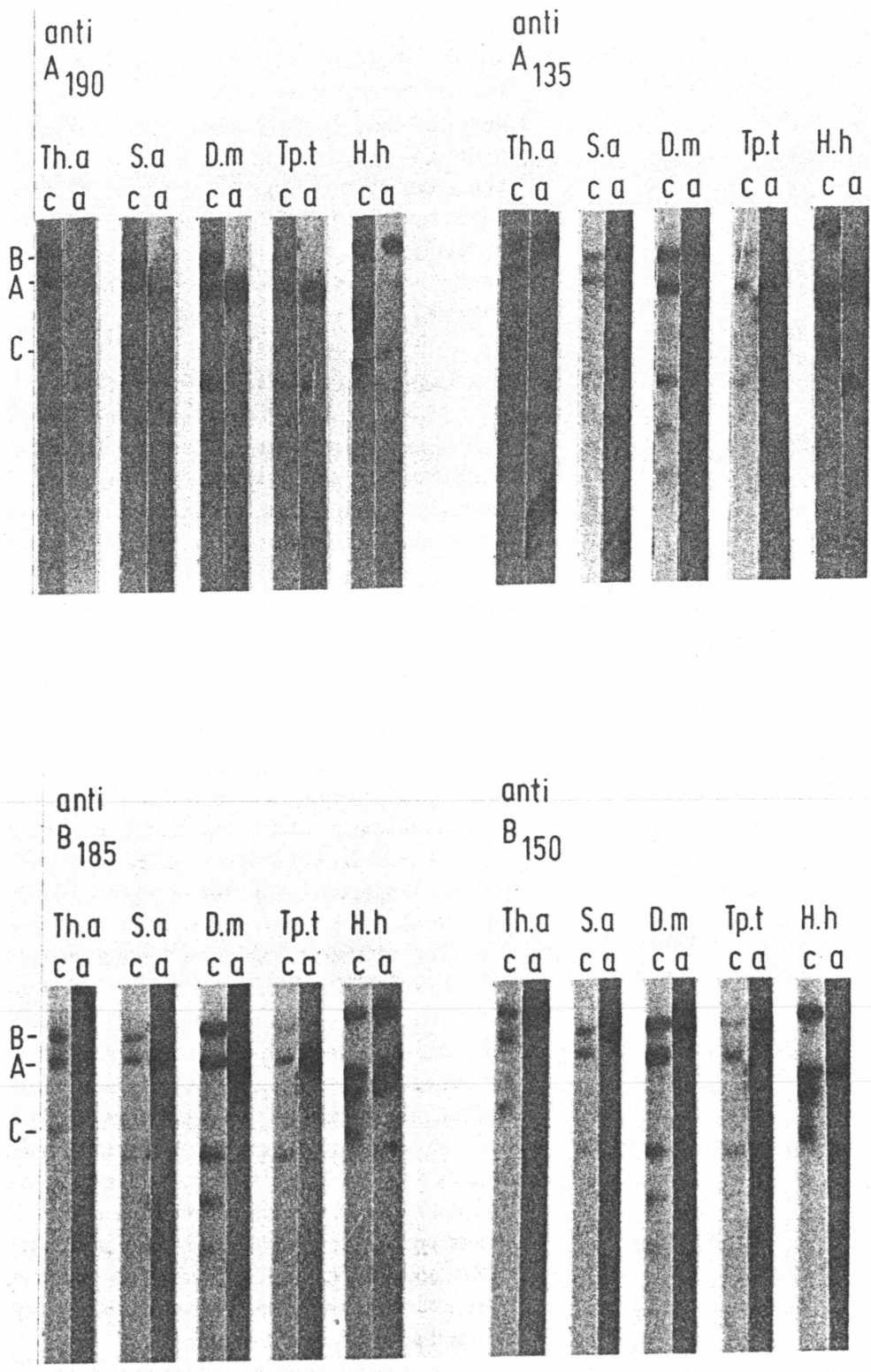


silybin, which is isolated from the thistle Silybium marianum, stimulates about twofold transcription by the RNA polymerases from the thermoacidophilic archarchaebacteria (R. Schnabel et al., 1982a) and eukaryotes, i.e., RNA polymerase I(A) (Machicao and Sonnenbichler, 1977). The stimulation affects the elongation, not the initiation, phase. The drug does not stimulate transcription either by eubacterial or by the other eukaryotic RNA polymerases (II and III), indicating (like the component patterns and the immunochemical data do) that, among eukaryotic polymerases, form I might be closest to the archaebacterial enzyme.

\section{Conclusions}

1. These data divide the archaebacterial RNA polymerases into two types: those from the thermoacidophilic (or sulfur-dependent) groups and those from the methanogenic (and extremely halophilic) archaebacterial groups. Except for Thermoplasma, this division also follows from comparative cataloging of $16 \mathrm{~S}$ rRNAs (Fox et al., 1980; Woese et al., 1984), from $16 \mathrm{~S}$ rRNA-DNA crosshybridization (Tu et al., 1982), and from $5 \mathrm{~S}$ rRNA (Fox et al., 1982) and initiator tRNA (Kuchino et al., 1982) sequences, indicating that the primary kingdom of the archaebacteria consists of two main branches (see review on thermoacidophiles including sulfur-dependent archaebacteria).

The exception, Thermoplasma, which has an RNA polymerase of the "thermoacidophilic type," appears closer to the methanogen branch (or in an isolated or bridging position) with respect to other phenotypic features (see Chapter 2 on Thermoplasma in review on thermoacidophiles).

2. At least in a few instances components of RNA polymerases of all three primary kingdoms show immunochemical homologies with each other, indicating that all RNA polymerases are derived from a common ancestor.

3. The strikingly extensive homology between archaebacterial and nuclear eukaryotic RNA polymerases points to a relationship between these two primary kingdoms that is closer than either has with the eubacteria. Compared to the polymerases of archaebacteria and eukaryotes, which are of the same basic type, the eubacterial enzymes appear to have evolved further, into a distinct type. In contrast, the eukaryotic RNA polymerases I and II and probably also III originate from an ancestral type resembling the archaebacterial enzyme. The separate evolution of the three types of eukaryotic enzymes should have followed the division of archaebacteria from "urkaryotes." Both branches of archaebacteria appear equally related to eukaryotes in this respect. In other features, e.g., $5 \mathrm{~S}$ rRNA and tRNA, the similarities between eukaryotes and Sulfolobus appear more extensive than those between eukaryotes and Thermoplasma and between the methanogens and halophiles.

An increasing body of evidence appears to support this view: Ribosomal A 
proteins (Matheson and Yaguchi, 1982), EFII (Kessel and Klink, 1982), some characteristics of $5 \mathrm{~S}$ rRNA (Fox et al., 1982) and initiator tRNA (Kuchino et al., 1982), the occurrence of glycoproteins, and the apparent absence of guanosine tetra- and pentaphosphates resemble the corresponding features in eukaryotes rather than eubacteria.

\section{Purification of Archaebacterial RNa Polymerases}

With the exception of the enzymes from Halobacterium (Zillig et al., 1978; Madon and Zillig, 1983), Halococcus (Madon et al., 1983), Methanococcus, and Methanosarcina (Thomm, 1983), polymerases of archaebacteria were purified by a variation of the polymin $\mathrm{P}$ method originally used for the isolation of E. coli RNA polymerase (Zillig et al., 1979, 1980, 1983a.b; Sturm et al., 1980; Prangishvilli et al., 1982).

Steps involved were (1) preparation of a crude extract, often merely by suspension of cells in neutral buffer with the addition of a nonionic detergent, such as Triton X-100, for more sturdy organisms by means of a French press or sonication; (2) precipitation of nucleic acids plus bound and acidic proteins, including RNA polymerase with polymin P; (3) elution of proteins, including RNA polymerase from the washed precipitate at high ionic strength, followed by ammonium sulfate precipitation of the eluate: (4) DEAE chromatography of the redissolved and dialyzed precipitate. This step had to be omitted in the purification of the enzymes from Thermoproteus and Thermofilum, which did not adsorb; (5) heparin cellulose chromatography (Sternbach et al., 1975) of the active fractions of the previous step; (6) DNA cellulose chromatography (according to Alberts et al., 1968) and finally (7) sucrose glycerol gradient centrifugation. The buffer contained routinely $10^{-3} \mathrm{M}$ EDTA and $40 \% \mathrm{v} / \mathrm{v}$ glycerol. If required, concentration was effected with a hollow fiber concentrator (Berghof, Tübingen) or miniconcentrator (Schulz, 1982).

After sucrose glycerol gradient centrifugation, the enzymes were essentially pure. Peptide chains were considered components, if they co-purified with each other and with the activity in at least three steps of the purification, e.g., heparin cellulose and DNA cellulose chromatography and gradient centrifugation. Antisera against single components of Sulfolobus polymerase co-precipitated the other components except $\mathrm{H}$, demonstrating that 9 out of the 10 components are tightly linked (R. Schnabel, 1983). As long as the functions of the components remain unknown, the term component solely refers to this binding.

The RNA polymerases of Methanococcus thermolithotrophicus and Methanosarcina barkeri were inactivated in the polymin P step, possibly by dissociation. Therefore, the enzyme from Methanococcus was separated from the DNA by precipitation of the latter with polyethylene glycol $(6000)$ in the presence of 
high salt (Thomm, 1983). The RNA polymerase from Methanosarcina barkeri was separated from the DNA by hydrophobic interaction chromatography (Thomm, 1983), a method applied recently to the isolation of proteins from rat liver chromatin (Schafer-Nielson and Rose, 1982).

The enzyme from Methanosarcina barkeri could not be eluted in active form from DNA-cellulose. Therefore, single-stranded DNA agarose was used in this case instead.

The purification of the enzyme from $M$. barkeri was further complicated by its irreversible dissociation during sucrose glycerol-gradient centrifugation. It remained stable during BioGel A $1.5 \mathrm{~m}$ chromatography in the presence of $40 \%$ $(\mathrm{v} / \mathrm{v})$ glycerol. The enzymes of Methanococcus and Methanosarcina were both isolated in buffers containing $10^{-2} \mathrm{M} \mathrm{MgCl}_{2}$.

The greatest difficulties were encountered in the purification of the RNA polymerase from Halobacterium. The use of buffers of low ionic strength, allowing the application of "normal" purification strategies, became possible by addition of $40-50 \%(\mathrm{v} / \mathrm{v})$ glycerol and $0.025-0.05 \mathrm{M} \mathrm{Mg}^{2+}$. The test had to be performed at low ionic strength, because initiation of transcription did not occur at high salt concentration. Precipitation by and elution off polymin P, which in most other cases led to the separation of RNA polymerase and DNA, did not work in this case. Initially, it was replaced by removal of DNA with DNase, followed by sizing (Zillig et al., 1978). But the polymerase obtained after this step was neither completely DNA dependent nor able to transcribe native DNA, probably because it contained short pieces of bound residual DNA. This difficulty was surmounted by introducing phase partitioning steps for the separation of the enzyme from the DNA (Madon and Zillig, 1983). The enzyme purified in this manner contained an additional component required for transcription of DNA including native DNA, but the component was not absolutely required for that of poly[d(AT)]. However, polymerase prepared in this way is still unable to initiate transcription at high ionic strength, though elongation occurs at high salt. This problem, thus, remains to be solved.

\section{E. Different Forms and Fragments of Archaebacterial RNA POLYMERASES}

In several steps of the purification procedure, e.g., heparin cellulose and DNA cellulose chromatography, separate peaks of enzyme activity were observed. Sometimes, the component patterns of such forms appear indistinguishable, e.g., in the case of Sulfolobus acidocaldarius (Zillig et al., 1979) where they separated in heparin cellulose chromatography and exhibited equal activities on poly[d(AT)] but different activities with native DNA templates. However, two forms of the RNA polymerase of Desulfurococcus were distinguished by the 
presence or absence of an additional component, in SDS-polyacrylamide gel electrophoresis migrating just in front of component C (Prangishvilli et al., 1982) (Fig. 1).

A form of the polymerase of Thermoplasma has been distinguished from another by decreased affinity for its component $\mathrm{D}$, which could be partially removed upon consecutive purification (Sturm et al., 1980).

The RNA polymerases of Halobacterium (Madon and Zillig, 1983) and Halococcus (Madon et al., 1983) exhibit a double band in place of component C in SDS-polyacrylamide gel electrophoresis (Fig. 6). Both C components sum up to one peptide chain per enzyme monomer. As revealed by cellogel electrophoresis, their charge densities differ (Zillig et al., 1978). It appears possible that one is formed by modification of the other.

Analysis of fractions obtained in purification steps by SDS-polyacrylamide gel electrophoresis revealed the occurrence of inactive enzyme fragments. Thermoplasma acidophilum yielded a fragment devoid of components $\mathrm{C}$ and $\mathrm{E}$ (Sturm et al., 1980), Halobacterium (Fig. 7), and Methanobacterium fragments lacking component A (Madon and Zillig, 1983; Stetter et al., 1980). The corresponding released component $\mathrm{A}$ was eluted in a different position in heparin cellulose chromatography. In the case of Halobacterium, more than $80 \%$ of the enzyme components were found in the fragments eluting in front of the native enzyme peak.

RNA polymerase from Methanococcus thermolithotrophicus purified by a procedure in which the polyethylene glycol precipitation step was replaced by hydrophobic interaction chromatography contains an additional component migrating between components $\mathrm{C}$ and $\mathrm{D}$ (see Fig. 1). When the heparin cellulose chromatography step was omitted, three additional components, one between $\mathrm{B}^{\prime}$ and $\mathrm{B}^{\prime \prime}$ and two more between $\mathrm{C}$ and D, were observed (Fig. 1). All of these did not cross-react immunochemically with any other component. In contrast, an additional band found in a preparation of $M$. thermoautotrophicum RNA poly-

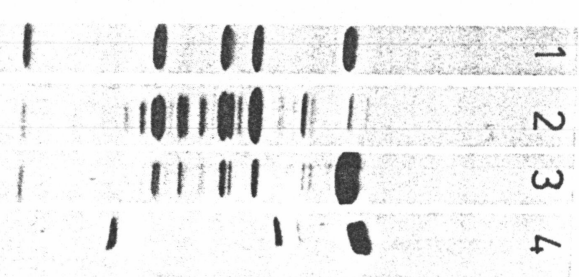

Fig. 6. SDS-polyacrylamide slab gel electrophoretogram of purified DNA-dependent RNA polymerases from Halobacterium halobium (track 1) and of fragment from heparin cellulose chromatography lacking component $\mathrm{A}$ and of the corresponding released fragment $\mathrm{A}$ from the same chromatography (tracks 2 and 3). RNA polymerase from E. coli (track 4). 


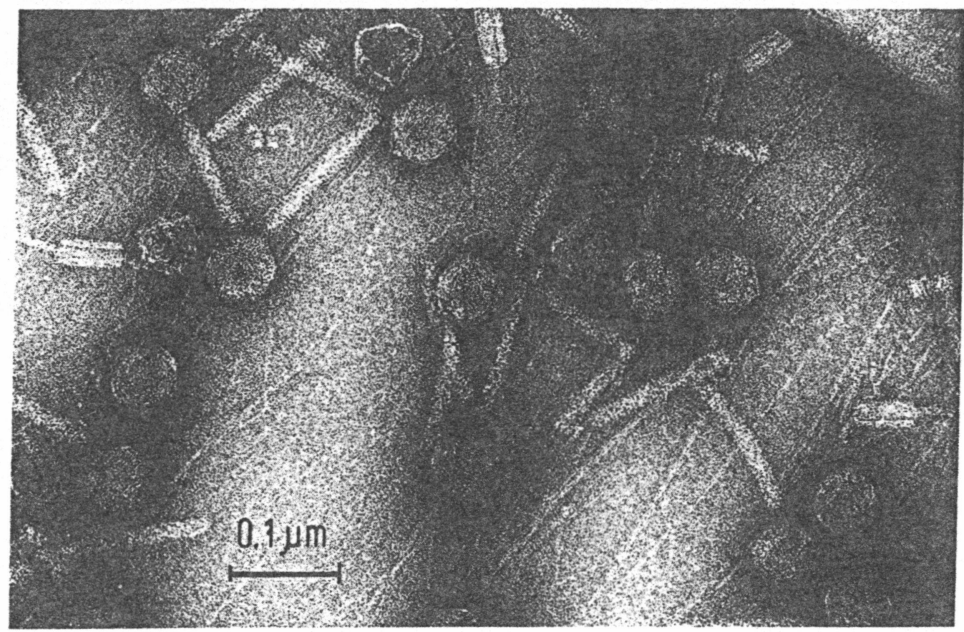

Fig. 7. Phage $\phi \mathrm{H}$ negatively stained with uranyl acetate. The bar represents $0.1 \mu \mathrm{m}$. (Electron micrograph courtesy of L. Hintermaier and E. Demm.)

merase was serologically related to component $\mathrm{A}$ and thus appeared to be a proteolytic cleavage product of the latter (Schnabel et al., 1983). On poly[d(AT)] as template, no significant differences in the specific activities of all these different forms were observed.

It should be emphasized, that the term form in this context does not have the same meaning as for nuclear eukaryotic polymerases but merely indicates that different fractions of an enzyme can be distinguished either by being separated during purification and/or by their component patterns or other features. Some of these forms could be products of partial denaturation rather than having certain functions in in vitro transcription. The latter possibility has however not been excluded.

\section{F. Function of RNA Polymerase Components}

So far, only in a few instances is information pertaining to the role of polymerase components in the transcription process available.

Different preparations of Sulfolobus polymerase contain different, substoichiometric, sometimes insignificant amounts of component F. But no related difference in the specific activities was found. An inactive fraction of Sulfolobus polymerase, which was not bound to native DNA cellulose at $70^{\circ} \mathrm{C}$, lacks all components smaller than E (Schnabel, 1983). Two fractions equally active on 
various templates were consecutively eluted in a salt gradient from a DNAcellulose column at $70^{\circ} \mathrm{C}$. In the less tightly bound fraction, component $\mathrm{F}$ was absent. The fraction eluting at higher salt concentration lacked components $\mathrm{F}$ and $\mathrm{H}$, both of which do not appear to influence the in vitro overall activity of the enzyme (R. Schnabel, 1983). However, this does not exclude the possibility that components $\mathrm{F}$ and $\mathrm{H}$ are involved in transcription in vivo.

Component $\mathrm{E}$ of the RNA polymerase of Thermoplasma is required for, but released upon, tight binding of the enzyme to certain productive sites of the DNA (R. Schnabel et al., 1982b). It is also required for the transcription of native DNA. The homologous component E of Sulfolobus polymerase is not released under comparable conditions, indicating considerable differences in the function of homologous proteins in different genera of archaebacteria.

A form of the RNA polymerase of Halobacterium lacking component $\epsilon$ (thus termed because its homology with the components of other archaebacterial polymerases has not yet been established) is unable to transcribe native and denatured DNA but shows significant activity on poly[d(A.T)] (Madon and Zillig, 1983).

Two nearly inactive fractions containing components of the RNA polymerase of Thermoplasma were separated by cellogel electrophoresis. The activity was restored by recombination, indicating reconstitution (Schnabel, 1983). However, the inactive fragments, A and enzyme without A, of the Halobacterium polymerase did not yield an active reconstitution product. Techniques for the complete dissociation and reconstitution, which could greatly facilitate the investigation of component function, have not yet been worked out for archaebacterial RNA polymerases.

\section{G. IN VITRo TRANSCRIPTION BY ARCHAEBACTERIAL RNA POLYMERASES}

Though the optimal ionic strength and magnesium concentrations for the transcription by different archaebacterial RNA polymerases vary considerably, all enzymes isolated so far, including that from Halobacterium, work best at low ionic strength. The optimal temperatures for transcription by enzymes from extreme thermophiles vary for different enzymes and templates, but are usually around $80^{\circ}-90^{\circ} \mathrm{C}$. Several RNA polymerases of extreme thermophiles, most prominently that from Thermoproteus, are still entirely stable at temperatures not allowing transcription of naked DNA in vitro (at least $95^{\circ} \mathrm{C}$ in the case of the polymerase from Thermoproteus). Because such organisms grow at temperatures exceeding those optimal for in vitro transcription of naked native DNA, and even above the $\mathrm{T}_{\mathrm{m}}$ 's of the latter, it appears that stabilization of the template, e.g., by proteins or polyamines, must occur in vivo. Basic DNA binding proteins have indeed been found in archaebacteria (Searcy, 1975; Thomm et al., 1982). 
The abilities of different archaebacterial RNA polymerases to transcribe native DNAs and their overall transcription activities on different templates vary widely (Table I). The specific activities of the RNA polymerases of Thermoplasma and Halobacterium are much higher on poly[d(A.T)] than on native DNAs (3-20 times and more than 20 times, respectively). The specific activities of other enzymes are each near to that for $E$. coli RNA polymerase on certain templates, different for different polymerases, but low or insignificant on others, indicating genus-dependent template specificity, possibly in signal recognition.

The most striking example is that of Desulfurococcus RNA polymerase, for which phage T7 and pBR322 DNAs (both containing AT-rich sequences) are excellent but for which phage T4 and T5 DNAs are weak templates (in spite of their strong eubacterial promoters). This polymerase also transcribes T7 DNA asymmetrically, though not from its eubacterial promoters (Prangishvilli et al., 1982).

\section{H. Homologous Templates}

The investigation of in vitro transcription by DNA-dependent RNA polymerases of archaebacteria requires homologous templates, possibly "chromatins." Such templates could be virus (phage) DNAs, plasmids, or cloned genes.

In the Halobacterium halobium system, a large satellite DNA (Moore and McCarthy, 1969) has been shown to contain a circular, superhelical plasmid of extreme genetic variability (Pfeifer et al., 1981a,b), due to recombination in which many families of repetitive sequences are involved (Sapienza and Doolittle, 1982). However, genes have so far not been satisfactorily identified in this large genome.

The halobacteriophage $\phi \mathrm{H}$ (Fig. 7) is a temperate virus with linear DNA of 59,000 basepairs, which shows partial circular permutation (H. Schnabel et al., 1982a). The DNA is a mixture of forms (Fig. 8) that are distinguished by inserts or deletions (Fig. 9), of which at least one insert is also present in the host plasmid (H. Schnabel et al., 1982b). At least two of these forms (2 and 5) are interconvertible by the inversion of a sequence flanked by identical inserts. This genetic variability is probably of the same nature as that observed in the plasmid. Three types of clones from immune strains of $H$. halobium carry the phage genome or parts of it: (1) true lysogens, which contain the prophage in superhelical circular form and give rise to phage progeny frequently, (2) quasilysogens, which contain the whole, possibly slightly altered, phage genome and are distinguished by a low incidence of phage production, and (3) cells containing the invertible sequence of the phage forms 2 and 5 looped out as a plasmid (Schnabel and Zillig, 1984; Schnabel, 1984). The identification of genes, e.g., those governing immunity, and their transcription in the phage genome, appears 


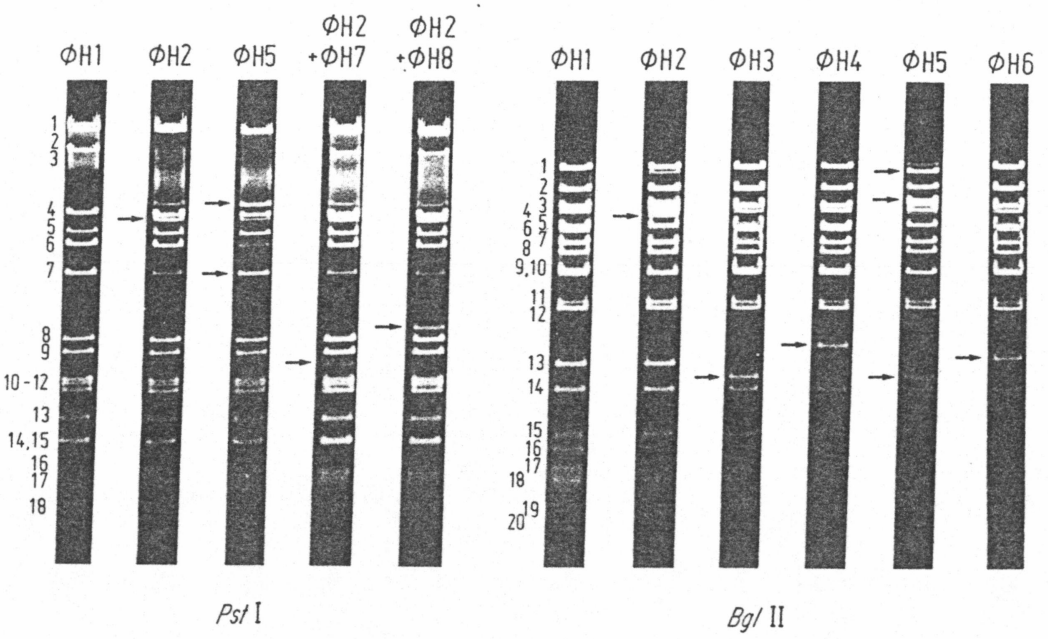

Fig. 8. Restriction endonuclease fragments of phage $\phi H$ DNA produced by the enzymes $B g$ lII or $P s t \mathrm{I}$ and separated by agarose gel electrophoresis. Phage $\phi \mathrm{H}$ exists as a mixture of variants, six of which have been isolated from single plaques. Their DNAs differ in structure, as shown by restriction fragments (arrows) that are not present in the DNA of the predominant variant $\phi \mathrm{H} 1 . \phi \mathrm{H} 7$ and $\phi \mathrm{H} 8$ have not yet been isolated and are so far characterized by new minor fragments in mixtures of $\phi \mathrm{H} 7$ or $\phi \mathrm{H} 8$ with $\phi \mathrm{H} 2$.

straightforward. Unfortunately, the homologous RNA polymerase is yet unable to initiate in vitro transcription on native DNA at high ionic strength, possibly due to some deficiency, which could also involve the state of the template.

In the Sulfolobus acidocaldarius system, two plasmids have been identified and cloned, in parts or entirely, into $E$. coli vectors.

The plasmid $\mathrm{pB} 12$ of strain B12 of $S$. acidocaldarius, 15 kilobase pairs (kbp) long, exists integrated into a specific site of the host genome as well as in a free superhelical circular state (Yeats et al., 1982). Ultraviolet induction leads to strong amplification accompanied by the breakdown of the host genome. The plasmid proved to be the genome of a virus-like particle (Martin et al., 1984).

A plasmid pB6 of strain B6 of $S$. acidocaldarius (33 kbp) exists in different forms carried by different Sulfolobus clones, two of which are distinguished by an inversion, as well as other differences. The original isolate, from which the plasmid-carrying clone has been derived, contained virus-like particles in hexagonally packed crystalline arrays. The relationship between plasmid and virus is not understood. This plasmid has also been cloned into pBR322 and is the subject of genetic analysis (S. Yeats, P. McWilliam, and H. Neumann, unpublished). 
Immunochemical cross-reactions between RNA polymerases of different archaebacteria, as revealed by the Western blotting technique that employs iodinated Staphylococcus protein A or antibody-coupled peroxidase, have been found throughout the archaebacteria among components of medium size or larger (see above). They form a strong basis for the establishment of the two main branches of this primary kingdom.

However, precipitation, which is the basis for Ouchterlony's in-gel immunodiffusion test, does not occur between a polymerase antiserum and a polymerase from a member of a different family (K. O. Stetter, unpublished). The presence or absence of a cross-reaction in the Ouchterlony's test can thus be used as criterion for phylogenetic distance. In a negative case, the difference is large enough to postulate different families, as was done for the taxonomic classification of the novel genera Thermoproteus, Desulfurococcus, Thermofilum, and Thermococcus within the order Thermoproteales (see review on this subject in this volume, Chapter 2) and of the family Methanothermaceae within the Methanobacteriales (Stetter et al., 1980).

On the other hand, cross-reaction of the polymin $\mathrm{P}$ eluate of a novel isolate with an available antibody in the Ouchterlony test shows that the isolate is closely related to the source of the antigen. It also allows the immunochemical isolation of the RNA polymerase in question and thus its detailed comparison to those of other archaebacteria (Prangishvilli et al., 1982).

So far, RNA polymerase structure belongs to the syntactic rather than semantophoretic features in a phylogenetic analysis (Balch, 1982). It appears, however, that RNA polymerase is a conservative molecule, probably as suitable for comparative sequence analysis as is ribosomal RNA.

\section{Note Added in Proof}

A later account of this topic containing further information is: Zillig. W., Schnabel, R., Stetter, K. O., Thomm, M., Gropp, F., and Reiter, W. D. (1985). The evolution of the transcription apparatus. In "The Evolution of the Prokaryotes" (K. H. Schleifer and E. Stackebrandt, eds.). Academic Press, Orlando.

\section{REFERENCES}

Alberts, B., Amodio, F., Jenkins, M., Goodman, E., and Ferris, F. (1968). Studies with DNAcellulose chromatography. I. DNA binding proteins from Escherichia coli. Cold Spring Harbor Symp. Quant. Biol. 33, 289-305.

Babinet, C. (1976). A new method for the purification of RNA-polymerase. Biochem. Biophys. Res. Commun. 26, 639-644.

Balch, W. E. (1982). Methanogens: Their impact on our concept of procaryotic diversity. Zentralbl. Bakteriol., Mikrobiol. Hyg., Abt. 1, Orig. C 3, 295-303.

Burgess, R. R. (1976). Purification and properties of $E$. coli polymerase. In "RNA Polymerase" (R. Losick and M. Chamberlin, eds.), pp. 69-100. Cold Spring Harbor Lab., Cold Spring Harbor, New York. 

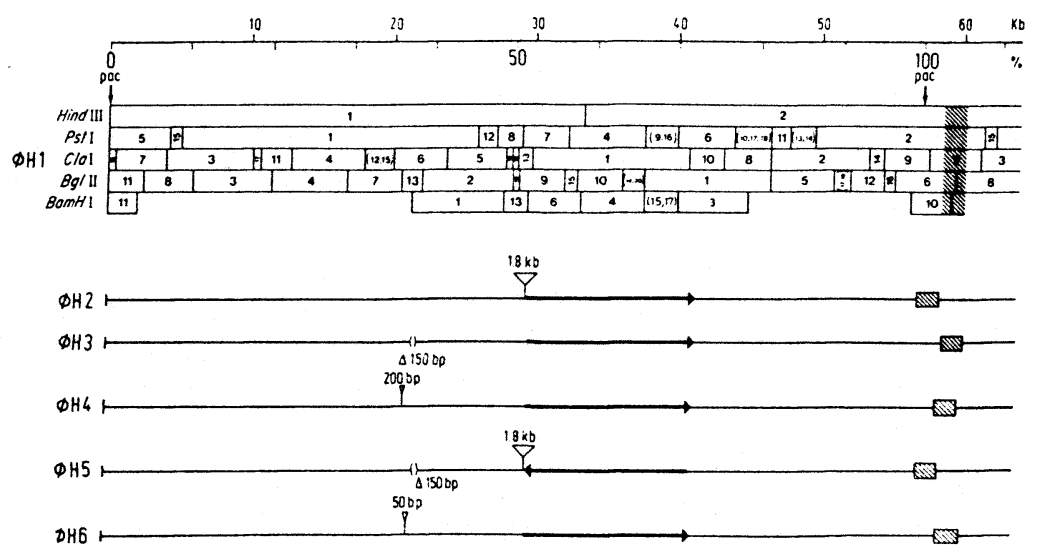

Fig. 9. Map of restriction fragments of $\phi H \mathrm{DNA}$ and structural differences between the variants. Compared to the predominant variant $\phi \mathrm{H} 1$, three types of changes are observed: (a) insertions of $1.8 \mathrm{kbp}, 200 \mathrm{bp}$, or $50 \mathrm{bp}$; (b) a deletion of $150 \mathrm{bp}$; (c) an inversion of $11 \mathrm{~kb}$ (heavy arrow). The phage DNA is partially circularly pernuted and terminally redundant. Phages contain linear DNA of $59 \mathrm{~kb}$, corresponding to $103 \%$ of the $\phi \mathrm{H} 1$ genome. Insertions and deletions affect the ends of phage DNA molecules (shaded regions) because DNA length is determined by size of the phage head.

Of 15 isolates of the orders Methanomicrobiales and Methanococcales, only one, PL 12/M (belonging to the Methanomicrobiales), yielded a plasmid, pMP 1 of $7.0 \mathrm{kbp}$, which appears to exist in a free state as well as integrated in the chromosomal DNA (Thomm et al., 1983). It was isolated from the pellet fraction rather than from the cleared lysate; it has been cloned in pBR322.

The structural genes for $16 \mathrm{~S}$ and $23 \mathrm{~S}$ rRNA of Thermoplasma acidophilum. which (as those for $5 \mathrm{~S}$ rRNA) are unlinked to other rRNA genes within the genome, have been cloned into pBR322 (Tu and Zillig, 1982) and into cosmids (R. Schnabel, unpublished).

These studies have not yet approached the main goal of such work-the identification of transcription signals and the establishment of a "correct" in vitro transcription system-but they appear to have opened the way.

\section{Polymerase Structure and Taxonomy}

The usefulness of RNA polymerase structure for taxonomy has been discussed previously (Zillig and Stetter, 1980). The insensitivity of archaebacterial RNA polymerases to rifampicin and streptolydigin (already in the completely DNAdependent polymin $\mathrm{P}$ eluate) is an easily established criterion for the possible archaebacterial nature of a novel isolate. 
Burnette, W. N. (1981). "Western blotting": Electrophoretic transfer of protein from sodium dodecyl sulfate-polyacrylamide gels with antibody and radioiodinated protein A. Anal. Biochem. 112, 195-203.

Fox, G. E., Stackebrandt, E., Hespell, R. B., Gibson, J., Maniloff, J., Dyer, T. A., Wolfe, R. S., Balch, W. E., Tanner, R. S., Magrum, L. J., Zablen, L. B., Blakemore, R., Gupta, R., Bonen, L., Lewis, B. J., Stahl, D. A., Luehrsen, K. R., Chen, K. N., and Woese, C. R. (1980). The phylogeny of prokaryotes. Science 209, 457-463.

Fox, G. E., Luehrsen, K. R., and Woese, C. R. (1982). Archaebacterial 5s ribosomal RNA. Zentralbl. Bacteriol., Mikrobiol. Hyg., Abt. I, Orig. C 3, 330-345.

Gierl, A., Zillig, W., and Stetter, K. O. (1982). The role of components and of the DNA-dependent RNA polymerase of Lactobacillus curvatus in promoter selection. Eur. J. Biochem. 125, 4147.

Halling, S. M., Burtis, K. C., and Doi, R. H. (1978). $\beta^{\prime}$ subunit of bacterial RNA polymerase is responsible for streptolydigin resistance in Bacillus subtilis. Nature (London) 272, 837-839.

Heil, A., and Zillig, W. (1970). Reconstitution of bacterial DNA-dependent RNA polymerase from isolated subunits as a tool for the elucidation of the role of the subunits in transcription. FEBS Lett. 11, 165.

Huet, J., Sentenac, A., and Fromageot, P. (1982). Spot-immunodetection of conserved determinants in eukaryotic RNA polymerases. J. Biol. Chem. 257, 2613-2618.

Huet, J., Schnabel, R., Sentenac, A., and Zillig, W. (1983). Archaebacteria and eukaryotes posses DNA-dependent RNA polymerases of a common type. EMBO J. 2, 1291-1294.

Ishihama, A., and Ito, K. (1972). Subunits of RNA polymerase in function and structure. II. Reconstitution of E. coli RNA polymerase from isolated subunits. J. Mol. Biol. 72, 111-123.

Kessel, M., and Klink, F. (1982). Identification and comparison of 18 archaebacteria by means of the diphtheria toxin reaction. Zentralbl. Bakteriol., Mikrobiol. Hyg., Abt. 1, Orig. C 3, 140148.

Kuchino, Y., Ihara, M., Yabusaki, Y., and Nishimura, S. (1982). Initiator TRNAs from archaebacteria show common unique sequence characteristics. Nature (London) 298, 684-685.

Leib, C., Ernst, H., and Hartmann, G. R. (1980). Recognition of promoter sequences by RNA polymerase from different sources. Mol. Biol., Biochem. Biophys. 32, 301-307.

Lill, U. I., Behrendt, E. M., and Hartmann, G. R. (1975). Hybridization in vitro of subunits of the DNA-dependent RNA polymerase from E. coli and Micrococcus luteus. Eur. J. Biochem. 52, 411-420.

Machicao, F., and Sonnenbichler, J. (1977). Mechanism of the stimulation of RNA synthesis in rat liver nuclei by silybin. Hoppe-Seyler's Z. Physiol. Chem. 358, 141-147.

Madon, J., and Zillig, W. (1983). A form of the DNA-dependent RNA polymerase of Halobacterium halobium, containing an additional component, is able to transcribe native DNA. Eur. J. Biochem. 133, 471-474.

Madon, J., Leser, U., and Zillig, W. (1983). DNA-dependent RNA polymerase from the extremely halophilic archaebacterium Halococcus morrhuae. Eur. J. Biochem. 135, 279-283.

Martin, A., Yeats, S., Janekovic, D., Reiter, W. D., Aicher, W., and Zillig, W. (1984). SAV I, a temperate u.v.-inducible DNA virus-like particle from the archaebacterium Sulfolobus acidocaldarius isolate B12. EMBO J. 3, 2165-2168.

Matheson, A. T., and Yaguchi, M. (1982). The evolution of the archaebacterial ribosome. Zentralbl. Bakteriol., Mikrobiol. Hyg., Abt. 1, Orig. C 3, 192-199.

Moore, R. C., and McCarthy, B. J. (1969). Characterization of the deoxyribonucleic acid of various strains of halophilic bacteria. J. Bacteriol. 99, 248-254.

Palm, P., Heil, A., Boyd, D., Grampp, B., and Zillig, W. (1975). The reconstitution of E. coli DNA-dependent RNA polymerase from its isolated subunits. Eur. J. Biochem. 53, 283.

Pero, J., Nelson, J., and Fox, T. D. (1975). Highly asymetric transcription by DNA polymerase 
containing phage-SPOl-induced polypeptides and a new host protein. Proc. Natl. Acad. Sci. U.S.A. 72, 1589-1593.

Pfeifer, F., Weidinger, G., and Goebel, W. (1981a). Characterization of plasmids in halobacteria. $J$. Bacteriol. 145, 369-374.

Pfeifer, F., Weidinger, G., and Goebel, W. (1981b). Genetic Variability in Halobacterium halobium. J. Bacteriol. 145, 375-381.

Prangishvilli, J., Zillig, W., Gierl, A., Biesert, L., and Holz, I. (1982). DNA-dependent RNA polymerase of thermoacidophilic archaebacteria. Eur. J. Biochem. 122, 471-477.

Roeder, R. G. (1976). Eukaryotic nuclear RNA polymerase. In "RNA Polymerase" (R. Losick and M. Chamberlin, eds.), pp. 285-329. Cold Spring Harbor Lab., Cold Spring Harbor, New York.

Sapienza, C., and Doolittle, W. F. (1982). Unusual physical organization of the Halobacterium genome. Nature (London) 295, 384-389.

Schafer-Nielson, C., and Rose, C. (1982). Separation of nucleic acids and chromatin proteins by hydrophobic interaction chromatography. Biochim. Biophys. Acta 696, 323-331.

Schnabel, H. (1984). An immune strain of Halobacterium halobium carries the invertible L segment of phage $\phi \mathrm{H}$ as a plasmid. Proc. Natl. Acad. Sci. U.S.A. 81, 1017-1020.

Schnabel, H., and Zillig, W. (1984). Circular structure of the genome of phage $\phi \mathrm{H}$ in a lysogenic Halobacterium halobium. Mol. Gen. Genet. 193, 422-426.

Schnabel, H., Zillig, W., Pfäffle, M., Schnabel, R., Michel, H., and Delius, H. (1982a). Halobacterium halobium phage $\phi H$. EMBO J. 1, 87-92.

Schnabel, H., Schramm, E., Schnabel, R., and Zillig, W. (1982b). Structural variability in the genome of phage $\phi \mathrm{H}$ of Halobacterium halobium. Mol. Gen. Genet. 188, 370-377.

Schnabel, R. (1983). Untersuchungen zu Struktur und Funktion archaebakterieller RNA-Polymerasen. Ph.D. Thesis, Ludwig Maximilian University, Munich.

Schnabel, R., Sonnenbichler, J., and Zillig. W. (1982a). Stimulation by Silybin, a eukaryotic feature of archaebacterial RNA polymerases. FEBS Lett. 150, 400-402.

Schnabcl, R., Zillig. W., and Schnabel. H. (1982b). Component E of the D.NA-dependent R.NA polymerase of the archaebacterium Thermoplasma acidophilum is required for the transcription of native DNA. Eur. J. Biochem. 129, 473-477.

Schnabel, R., Thomm, M., Gerardy-Schahn, R., Zillig. W.. Stetter, K. O., and Huet, J. (1983). Structural homologies between different archaebacterial DNA-dependent RNA polymerases analysed by immunochemical comparison of their components. EMBO J. 2, 751-755.

Schulz, W. (1982). Untersuchungen zur Initation der Transkription in E. coli. Ph.D. Thesis, Ludwig Maximilian University, Munich.

Searcy, D. G. (1975). Histone like protein in the prokaryote Thermoplasma acidophilum. Biochim. Biophys. Acta 395, 535-547.

Sternbach, H., Engelhardt, R., and Lezius, A. G. (1975). Rapid isolation of highly active RNA polymerase from $E$. coli and its subunits by matrix bound heparin. Eur. J. Biochem. 60, 51-55.

Stetter, K. O. (1977). DNA-dependent RNA polymerase from Lactobacillus. Hoppe-Seyler's $Z$. Physiol. Chem. 358, 1093-1104.

Stetter, K. O., and Zillig, W. (1974). Transcription in Lactobacillus DNA-Dependent RNA polymerase from Lactobacillus curvatus. Eur. J. Biochem. 48, 527-540.

Stetter, K. O., Winter, J., and Hartlieb, R. (1980). DNA-dependent RNA polymerase of the archaebacterium Methanobacterium thermoautotrophicum. Zentralbl. Bakteriol., Mikrobiol. Hyg., Abt. 1, Orig. C 1, 201-218.

Stetter, K. O., Thomm, M., Winter, J., Wildgruber, G., Huber, H., Zillig, W., Janekovic, D., König, H., Palm, P., and Wunderl, S. (1981). Methanothermus fervidus, sp. nov, a novel extremely thermophilic methanogen isolated from an Icelandic hot spring. Zentralbl. Bakteriol., Mikrobiol. Hyg., Abt. 1, Orig. C 2, 166-178.

Sturm, S., Schönefeld, V., Zillig. W.. Janekovic, D., and Stetter, K. O. (1980). Structure and 
function of the DNA dependent RNA polymerase of the archaebacterium Thermoplasma acidophilum. Zentralbl. Bakteriol., Mikrobiol. Hyg., Abt. I, C 1, 12-25.

Thomm, M. (1983). Aufbau, Eigenschaften und immunologische Verwandtschaft der DNA-abhängigen RNA polymerasen methanogener Bakterien. Ph.D. Thesis, University of Regensburg.

Thomm, M., Stetter, K. O., and Zillig, W. (1982). Histone-like proteins in Eu- and Archaebacteria. Zentralbl. Bakteriol., Mikrobiol. Hyg.. Abt. I, Orig. C 3, 128-139.

Thomm, M., Altenbuchner, J., and Stetter, K. O. (1983). Evidence for a plasmid in a methanogenic bacterium. J. Bacteriol. 153, 1060-1062.

Towbin, H., Staehelin, T., and Gordon, J. (1979). Electrophoretic transfer of proteins from polyacrylamide gels to nitrocellulose sheets: Procedure and some applications. Proc. Natl. Acad. Sci. U.S.A. 76, 4350-4354.

Tu, J., and Zillig, W. (1982). Organization of rRNA structural genes in the archaebacterium Thermoplasma acidophilum. Nucleic Acids Res. 10, 7231-7245.

Tu, J., Prangishvilli, D., Huber, H., Wildgruber, G., Zillig. W., and Stetter, K. O. (1982). Taxonomic relations between archaebacteria including 6 novel genera examined by crosshybridization of DNAs and 16SrRNAs. J. Mol. Evol. 18, 109-114.

Wiggo, J. L., Bush, J. W., and Chamberlin, M. (1979). Utilization of promoter and terminator sites on bacteriophage T7 DNA by RNA polymerases from a variety of bacterial orders. Cell 16, 97109.

Woese, C. R., Gupta, R., Hahn, C. M., Zillig, W., and Tu, J. (1984). The phylogenetic relationships of three sulfur-dependent archaebacteria. Syst. Appli. Microbiol. 5, 97-105.

Yeats. S., McWilliam, P., and Zillig, W. (1982). A plasmid in the archaebacterium Sulfolobus acidocaldarius. EMBO J. 1, 1035-1038.

Zillig, W., and Stetter, K. O. (1980). In "Genetics and Evolution of RNA Polymerase, t-RNA and Ribosomes" (S. Osawa, H. Ozeki, H. Uchida, and T. Yura, eds.), pp. 525-538. Univ. of Tokyo Press, Tokyo.

Zillig, W.. Palm. P., and Heil, A. (1976). Function and reassembly of subunits of DNA-dependent RNA polymerase. In "RNA Polymerase"' (R. Losick and M. Chamberlin, eds.), pp. 101-126. Cold Spring Harbor Lab., Cold Spring Harbor, New York.

Zillig, W., Stetter, K. O., and Tobien, M. (1978). DNA-dependent RNA polymerase from Halobacterium halobium. Eur. J. Biochem. 91, 193-199.

Zillig, W., Stetter, K. O., and Janekovic, D. (1979). DNA dependent RNA polymerase from the archaebacterium Sulfolobus acidocaldarius. Eur. J. Biochem. 96, 597-604.

Zillig. W., Stetter, K. O., Wunderl, S., Schulz, W., Priess, H., and Scholz, I. (1980). The Sulfolobus "Caldariella" group: Taxonomy on the basis of the structure of DNA-dependent RNA polymerases. Arch. Microbiol. 125, 259-269.

Zillig, W., Stetter, K. O., Schnabel, R., Madon, J., and Gierl, A. (1982a). Transcription in Archaebacteria. Zentralbl. Bakteriol., Mikrobiol. Hyg., Abt. L, Orig. C 3, 218-227.

Zillig, W., Schnabel, R., Tu, J., and Stetter, K. O. (1982b). The phylogeny of archaebacteria, including novel anaerobic thermoacidophiles, in the light of RNA polymerase structure. Naturwissenschaften 69, 197-204.

Zillig, W., Gierl, A., Schreiber, G., Wunderl, S., Janekovic, D., Stetter, K. O., and Klenk, H. P. (1983a). The archaebacterium Thermofilum pendens represents a novel genus of the thermophilic, anaerobic sulfur respiring Thermoproteales. Syst. Appl. Microbiol. 4, 79-87.

Zillig, W., Holz, I., Janekovic, D., Schaefer, W., and Reiter, W. D. (1983b). The archaebacterium Thermococcus celer represents a novel genus within the thermophilic branch of the archaebacteria. Syst. Appl. Microbiol. 4, 88-94. 